\title{
WhatsApp as A Learning Media to Support Student's Reading Comprehension Skill
}

\author{
Beny Sasmiadi', Andayani², and Budhi Setiawan ${ }^{3}$ \\ \{benysasmiadi@student.uns.ac.id ${ }^{1}$, andayani@staff.uns.ac.id ${ }^{2}$, \& kaprodipbi@staff.uns.ac.id ${ }^{3}$ \} \\ 1,2,3 Universitas Sebelas Maret, Surakarta, Indonesia
}

\begin{abstract}
Science and technology have developed quickly in the world. It affects all aspects in various fields of live, including learning activities. The development of technology is not followed by student's learning skills. Student's reading comprehension skill is poor. Internet-based technology is only used to play game by students, so that time becomes. Now, the learning process can be done anytime and through various media, one of which is WhatsApp. As a digital technology-based social media, WhatsApp can be used to support learning activities. The purpose of this study is to observe the role WhatsApp as a learning media to support student's reading comprehension skill. The type of data in this study is qualitative. The data sources of this study are document and informant. Purposive sampling is considered more effective in various realities. In this study, to take the data used questionnaires arranged in a closed manner, while for data validity used data triangulation technique.This study is different from other studies because it specifically observes about the use internet-based social media applications to support student's reading comprehension skill. In general, students who learn by using WhatsApp as a learning media, have high motivation and have better reading comprehension skill.
\end{abstract}

Keywords: WhatsApp, Learning Media, Reading Comprehension Skill

\section{INTRODUCTION}

Reading as one of the subjects taught in Indonesian language lessons, is intended so that skilled students provide appropriate responses to various sources of information. In modern life with the rapid development of science and technology, the absorption of information through reading facilities for various purposes is something that cannot be abandoned. To be able to enjoy the development of information technology quickly and accurately, good reading skills are needed [1]. Various information has been packaged and delivered through various kinds of media such as television, radio, or the internet. Although the role of these media reduces the importance of the role of reading, the ability to read remains necessary to process and review information on certain forms of presentation in electronic media

Reading is one way of learning independent students to gain knowledge. Reading activities are not just looking at the entire contents of the writing, but using thinking skills to understand the contents of the reading. This is then referred to as students' reading comprehension skill 
[2]. In the learning process, reading is an absolute thing to do, because most knowledge is obtained through this activity. Student learning success will be determined from the reading skill of understanding possessed [3].

In the world of education and teaching, reading is an absolute thing to do. Most of the acquisition of knowledge is obtained by students through reading activities. The success of students in achieving progress and completing studies will be largely determined by their reading skill. The higher demands of the world of education compel everyone to have good learning techniques. The key to the success of learning outcomes lies in reading comprehension skills. For this reason, effective reading strategies are needed to develop reading comprehension skills [4]. The importance of reading comprehension in reality does not make students have high motivation to develop it. As a result students experience learning difficulties as a result of poor reading comprehension and language skills [5], [6].

The reading skills is not obtained naturally, but is formed through learning processes and special exercises. To improve reading comprehension skills, techniques and the use of appropriate learning media are needed. The existing learning process in fact is also a concern. Teachers always use conventional methods in learning activities. The use of learning media that is useful to support the learning process is often not done. At present, internet-based technology can be integrated into learning activities. One of the results of the technology is WhatsApp [7].

WhatsApp relations with learning activities are very close. The use of smartphone applications such as WhatsApp has contributed greatly to the field of language learning which includes four aspects including reading, writing, listening and speaking [8], [9]. In the learning process, WhatsApp makes it easy to send and receive text, audio recordings, and messages with visual content [10].

WhatsApp is the most popular application in the community. This application not only has chat functions, but also other functions [11]. The use of WhatsApp in learning activities has been widely carried out, including in Arabic (2013), Turkey (2013), English (2016), and India (2017), and all show good learning outcomes, especially in terms of language learning [12], [13], [14], [15]. The difference between this study and previous studies is that in this study, the use of WhatsApp as a direct learning media was focused on supporting students' reading comprehension skill.

\section{METHOD}

This research is descriptive qualitative with the main focus to describe and explain WhatsApp as a learning media to support students' reading comprehension skill. The main data sources are documents and informants related to the use of WhatsApp applications in learning activities. Data collection techniques using observation and questionnaires [16]. Data triangulation is used to check the validity of data by utilizing other things [17]. The triangulation technique used is data source triangulation and theory. Data analysis techniques use interactive chain analysis with steps including data collection, data reduction, data presentation, and taking conclusion.

The population of this study were foreign students in SMAN 6 Madiun, and the sample were 30 students who were randomly selected with the records of active users of WhatsApp. Before doing study of the effectiveness of the use of WhatsApp in reading comprehension skill, study on the level of use WhatsApp among students was first conducted. The next stage was to distribute the text of Indonesian language learning media for students who were already circulating on the internet or WhatsApp, and asked students to see and study it with an 
unspecified intensity. The provision was only one media in a week. After one week, in class meetings there was a follow-up phase to ensure the media had been watched and studied. Follow up was implemented by looking at student notes and frequently asked questions. The final stage after that was the evaluation of its implementation in the form of exercise questions. The results of all of these studies were the test scores of student's reading comprehension skill.

\section{RESULT AND DISCUSSION}

The world of information and communication technology (ICT), especially the internet grows rapidly. Almost in every aspects of life, ICT becomes the main tool used in office, cafes, schools, and houses which already use ICT. WhatsApp is one of the most popular social media applications in the world. As is known, WhatsApp is a messaging application for smartphones with basic similar to Facebook. This application makes it easy for users to communicate with each other or exchange information [18]. Easy access and lack of costs for communicating on WhatsApp are the main reasons people choose this application on their smartphone. This kind of social network will be more useful if used as a learning media, especially in reading comprehension material. Through this WhatsApp media, the rest is invited to grow and develop their reading comprehension skills

WhatsApp is a mobile messaging application that has more than 800 million users. The popularity of WhatsApp as an internet-based social media application is getting higher [19]. As one of the web-based social media, WhatsApp will be more optimal if it is connected via the internet network on cellphones, laptops, or computers. The advantage is clear, that every student will be able to study without being bound by time and place. This means that learning activities become something that is dynamic and flexible. To integrate the use of WhatsApp with learning to understand reading, there are several steps that must be taken.

The first step is to form a WhatsApp group consisting of 30 students who were sampled in this study, and a teacher. The teacher acts as the admin group only as a facilitator, the rest of the communication and learning activities in the WhatsApp group are more intended for active students.

The second stage is to start learning activities. The activity of learning to understand reading through WhatsApp can be done by dividing news texts obtained from the internet, newspapers and other sources. At this stage the teacher facilitates various types of reading texts and then shares them with WhatsApp grioup. Each student is asked to discuss the content and meaning contained in the readings provided.

The third stage is monitoring student activities. The use of WhatsApp which is not bound by space and time needs to be monitored so that the learning objectives do not deviate. The monitoring activity is carried out by the teacher by asking each student joined in the group to photograph the results of the study notes every day, and then the notes will later be submitted to the teacher.

Internet-based social networking will be very useful if used wisely. In social networks there is a virtual space that is used as a media for self-actualization activities with other users. The use of WhatsApp is one form of learning activities by reading, listening, listening, and speaking virtually. Various definitions and perceptions of students about WhatsApp, but in this study limited to some fundamental questions in the questionnaire. 
Table 1. The Student's Perception about WhatsApp

\begin{tabular}{|l|c|c|}
\hline \multicolumn{1}{|c|}{ Statement } & Agree & Not Agree \\
\hline I actively communicate on WhatsApp & $98 \%$ & $2 \%$ \\
\hline $\begin{array}{l}\text { I always communicate with my friend on } \\
\text { WhatsApp }\end{array}$ & $95 \%$ & $5 \%$ \\
\hline I only take the opportunity on WhatsApp & $60 \%$ & $40 \%$ \\
\hline
\end{tabular}

The table above shows students' perceptions of WhatsApp in learning activities. WhatsApp is used as a forum for scientific and social talks. From the table above clearly shows WhatsApp's popularity among students. As many as $98 \%$ of students admit that they actively communicate via WhatsApp, and 95\% like to communicate with friends with WhatsApp. But only $60 \%$ think they are taking advantage of the WhatsApp forum as a learning media. Different perceptions of students about the benefits of WhatsApp differ from one another. In lessons that require group wetting, it will allow differences of opinion. Some students are not serious about learning through learning media like WhatsApp. They only take advantage of smart friends. This situation is one of the obstacles to implementing WhatsApp in learning activities.

Through observations that have been made, students tend to work together and exchange ideas about learning on WhatsApp. Students who are usually passive during class learning look more active when communicating and exchanging ideas on WhatsApp social media. Indonesian language lessons that are closely related to reading material require high thinking skills. To understand reading, students need to have good reading skills. Teacher creativity, especially to combine technology-based learning media into the learning process is also important. WhatsApp as an internet-based learning media provides easy access to communication, so that each student will be able to interact in the WhatsApp group to solve their learning problems. The advantage is that each student can send each other pictures in the form of readings that will be studied together. Students who still do not understand the lesson, can exchange information via voicemail on WhatsApp, so that the learning objectives can be achieved well, in this case the students' reading ability is better. This is consistent with the results of research conducted by Khatun [20] that WhatsApp is proven to help students understand the lesson. Through empirical studies also found the suitability of the results that significantly saves WhatsApp to achieve learning goals [21].

Besides the benefits of using WhatsApp in learning activities, WhatsApp requires close supervision. The teacher must convince students to use WhatsApp for learning activities. The weakness of WhatsApp utilization is in according with the results of a study by Umar [22] that WhatsApp can be misused as for criminal purposes because the development of forensic tools develops more slowly than WhatsApp technology.

Based on the results of the study, some of the advantages and disadvantages of WhatsApp as a learning media to improve students' reading comprehension skills have been presented with various clear descriptions. From the aspect of excellence, WhatsApp has proven to be effective in supporting students' reading comprehension skills for the better. This can be interpreted that the combination of technology and science can be applied in various fields of learning. Students are not afraid to ask questions, express opinions or answers about learning because the interaction takes place in cyberspace. From the aspect of weakness, WhatsApp requires strict supervision of each student's learning activities. The teacher may find it difficult to supervise each student's learning activities when using WhatsApp [23]. 


\section{CONCLUSION}

Overall this study has shown students' perceptions of WhatsApp use in learning Indonesian, especially in the context of reading comprehension. Although there are limitations in its use, WhatsApp has proven to be able to support students' reading comprehension skills for the better. However, the teacher must be very careful and provide strict supervision of each student's learning activities so that the learning objectives can be achieved properly. This application can create learning conditions that are indirectly experienced by students' subconscious, so that information and knowledge can be received more clearly and completely.

\section{REFERENCE}

[1] P. Babashamsi, "An Overview on Reading Comprehension and Reading Speed," Int. J. Lang. Learn. Appl. Linguist. World, vol. 3, no. 12, pp. 2289-3245, 2013.

[2] A. Fakhruddin, "Reading Journal as a Way to Improve Students' Reading Comprehension," ETERNAL (English Teach. Journal), vol. 8, no. 2, 2018.

[3] K. Saddhono, "Language Usage of Foreign Students in Teaching Indonesian to Speakers of Other Languages (TISOL): Sociolinguistic Studies Based on Local Culture in Indonesia," 2018, pp. 817-821.

[4] A. Pourhosein Gilakjani and N. B. Sabouri, "How Can Students Improve Their Reading Comprehension Skill?,” J. Stud. Educ., vol. 6, no. 2, p. 229, 2016.

[5] K. Saddhono, "Language and superdiversity: Indonesians knowledging at home and abroad. By Zane Goebel,” Socioling. Stud., vol. 12, no. 1, pp. 113-118, 2018.

[6] J. L. Hosp et al., "Reading Assessment: Reading Fluency, Reading Fluently, and Comprehension--Commentary on the Special Topic.," School Psych. Rev., vol. 43, no. 1, pp. 29-49, 2014.

[7] I. O. Malecela, "Usage of Whatsapp among Postgraduate Students of Kulliyyah of Education, International Islamic University Malaysia,” Int. J. Adv. Eng. Res. Sci., vol. 3, no. 10, pp. 126-137, 2016.

[8] A. Al-Omary, W. M. El-Medany, and K. J. E. Isa, "The impact of SNS in higher education: A case study of using WhatsApp in the University of Bahrain," in Proceedings - 2015 5th International Conference on e-Learning, ECONF 2015, 2016, pp. 296-300.

[9] B. Ü. Karahan, "The Correlation of Reading Motivation \& Reading Engagement with Reading Comprehension Skills in $8^{\text {th }}$ Graders," Eur. J. Educ. Stud., vol. 3, no. 9, pp. 527-540, 2017.

[10] E. Flores-Salgado and T. A. Castineira-Benitez, "The use of politeness in WhatsApp discourse and move 'requests,"' J. Pragmat., vol. 133, pp. 79-92, 2018.

[11] A. Maniar and A. Modi, "Educating WhatsApp generation through WhatsApp," Zenith Int. J. Multidiscip. Res., vol. 4, no. 8, pp. 22-38, 2014.

[12] I. M. Aburezeq and F. F. Ishtaiwa, "The Impact of WhatsApps on Interaction in an Arabic Language Teaching Course.," Int. J. Arts Sci., vol. 6, no. 3, pp. 165-180, 2013.

[13] I. Journal, O. F. Social, and H. Studies, "the Impact of Social Media on Turkish University Students ' Attitudes Toward Online Advertising and," Int. J. Soc. Sci. Humanit. Stud., vol. 5, no. 1, pp. 92-105, 2013.

[14] N. I. B. M. A. (DL1632984) Nur Nadzirah Arina Binti Nadzri (DL1630130), Nurul Amirah Binti Ruzailani (DL1639552), Nurul Atika Binti Razali (DL1633314), Nor 
Arsida Binti M.Arshad (DL1639602), "Effect of Whatsapp Usage on Procurement Between Company and Vendors or Customers," English. pp. 8-10, 2016.

[15] P. Kiran, S. Vasantha, and A. Srivastava, "SEM modeling approach for studying the social impact of whatsapp usage," Indian J. Public Heal. Res. Dev., vol. 8, no. 2, pp. $268-272,2017$.

[16] J. A. Maxwell and L. E. Reybold, "Qualitative Research," in International Encyclopedia of the Social \& Behavioral Sciences: Second Edition, 2015, pp. 685-689.

[17] L. J. Moleong, "Metodologi Penelitian Kualitatif (Edisi Revisi)," in PT. Remaja Rosda Karya, 2017, p. 424

[18] A. D. Ahad and S. M. A. Lim, "Convenience or Nuisance?: The 'WhatsApp' Dilemma," Procedia - Soc. Behav. Sci., vol. 155, pp. 189-196, 2014.

[19] F. Karpisek, I. Baggili, and F. Breitinger, "WhatsApp network forensics: Decrypting and understanding the WhatsApp call signaling messages," Digit. Investig., vol. 15, pp. 110 118,2015

[20] A. Khatun and K. A. Al-Dhlan, "Effectiveness of WhatsApp," Int. J. Technol. Educ. Mark., vol. 7, no. 2, pp. 17-23, 2017.

[21] Ib. Ishtaiwa and F. Fayez, "The Impact of Whatsapp on Interaction in an Arabic Language Teaching Course,” Int. J. Arts Sci., vol. 6, no. 3, p. 6934, 2013.

[22] N. Aharony and T. Gazit, "The importance of the Whatsapp family group: an exploratory analysis," Aslib J. Inf. Manag., vol. 68, no. 2, pp. 174-192, 2016.

[23] K. Saddhono and M. Rohmadi, "A Sociolinguistics Study on the Use of the Javanese Language in the Learning Process in Primary Schools in Surakarta, Central Java, Indonesia." Int. Edu. Stu., vol. 7 no.6 pp 25-30, 2014 